\title{
New faunistic record of Schineriella schineri (Chironomidae: Diptera) from Slovakia
}

New faunistic record of Schineriella schineri (Chironomidae: Diptera) from Slovakia. - Acta Mus. Siles. Sci. Natur. 65: 149-151, 2016.

\begin{abstract}
The paper presents new faunistic record of Schineriella schineri (Strobl, 1880) for Slovakia from Číčov oxbow lake. Details on finding and notes on distribution and ecology are given.
\end{abstract}

Key words: Schineriella schineri, Chironomidae, first record, Slovakia

\section{Introduction}

New chironomid species for the fauna of Slovakia, Schineriella schineri (Strobl, 1880; Figs 2-4), was recorded from Č́́čov oxbow lake (Fig 1) within the national monitoring programme of surface water's status for 2015 year. Till now, 387 chironomid species are known from Slovakia. The findings contribute to the last checklist (Bitušik \& Brabec 2009, http://zoology.fns.uniba.sk/diptera2009).

Č́čov oxbow lake presents old Danube branch which was cut from the main stream by the creation of dike in the $19^{\text {th }}$ century. Most of its area belongs to the Nature reserve "Číčov oxbow lake" which is also included among wetlands of Ramsar Convention. Locality is important for its biodiversity, ecological and hydrological functions. In present it represents one of the most preserved Danube's oxbow lake situated out of river's flood area.

\section{Material and Methods}

Sampling was carried out from the bank by sweeping mostly the riparian macrophytes surface by hand net (mesh size $500 \mu \mathrm{m}$, frame $25 \mathrm{~cm}$ x $25 \mathrm{~cm}$ ). Even in the field the collected material was rinsed by water through the net (mesh size $500 \mu \mathrm{m}$ ) several times. Large debris was removed after being rinsed and inspected for clinging or sessile organizms. Then the material was placed into a plastic bottle, labeled, preserved with formaldehyde ( 4 $\%$ final concentration) and the sample was transported to the laboratory. Sorted larvae were mounted on microscopic slides and identified using the key by Bitušík \& Hamerlík (2014). The material is deposited in the author's collection at the Department of Hydrobiology, Microbiology and Ecotoxicology, Water Research Institute in Bratislava.

\section{New recorded species}

\section{SUBFAMILY TANYPODINAE}

\section{Schineriella schineri (Strobl, 1880)}

A species known from Austria, Belgium, Denmark, France, Germany, Great Britain, Hungary, Italy, Netherlands and Romania, East Palaearctic and Near East (Saether \& Spies 2013).

It occurs mainly in nutrient-rich ponds, pools and lakes, rarely in very slowly flowing waters. Larvae are intolerant of organic pollution (Wilson \& Ruse 2005, Vallenduuk \& Moller Pillot 2013). In the Neherlands larvae have been found regularly in mesotrophic lakes and also in eutrophic water bodies (Vallenduuk \& Moller Pillot 2013).

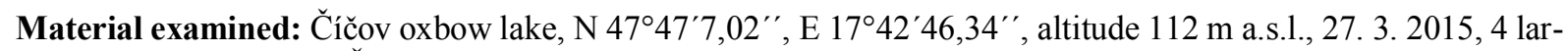
vae, M. Očadlík leg., S. Ščerbáková det. 


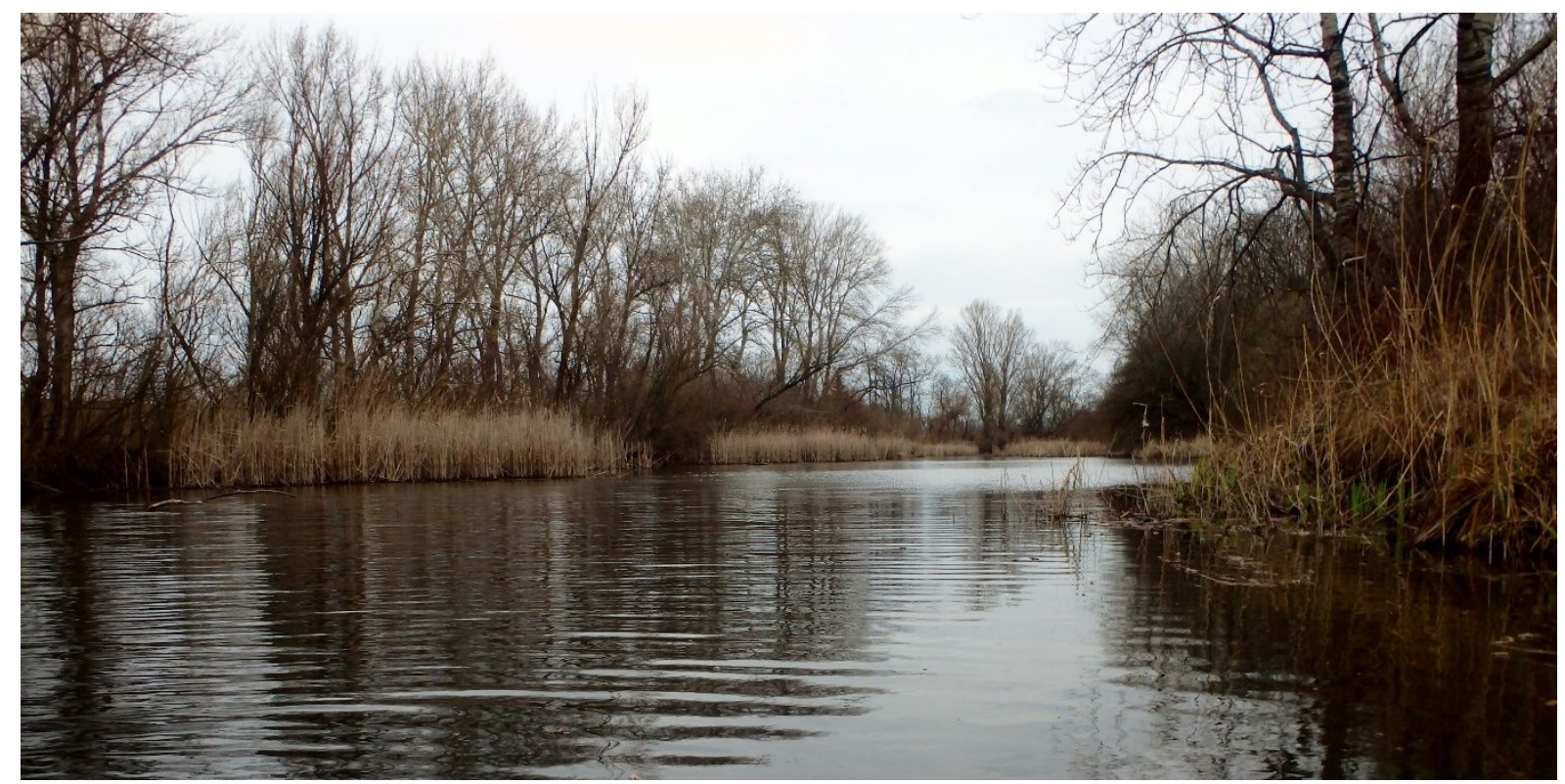

Fig 1: Sampling site, Č́íčov oxbow lake. Photo by M. Očadlík.

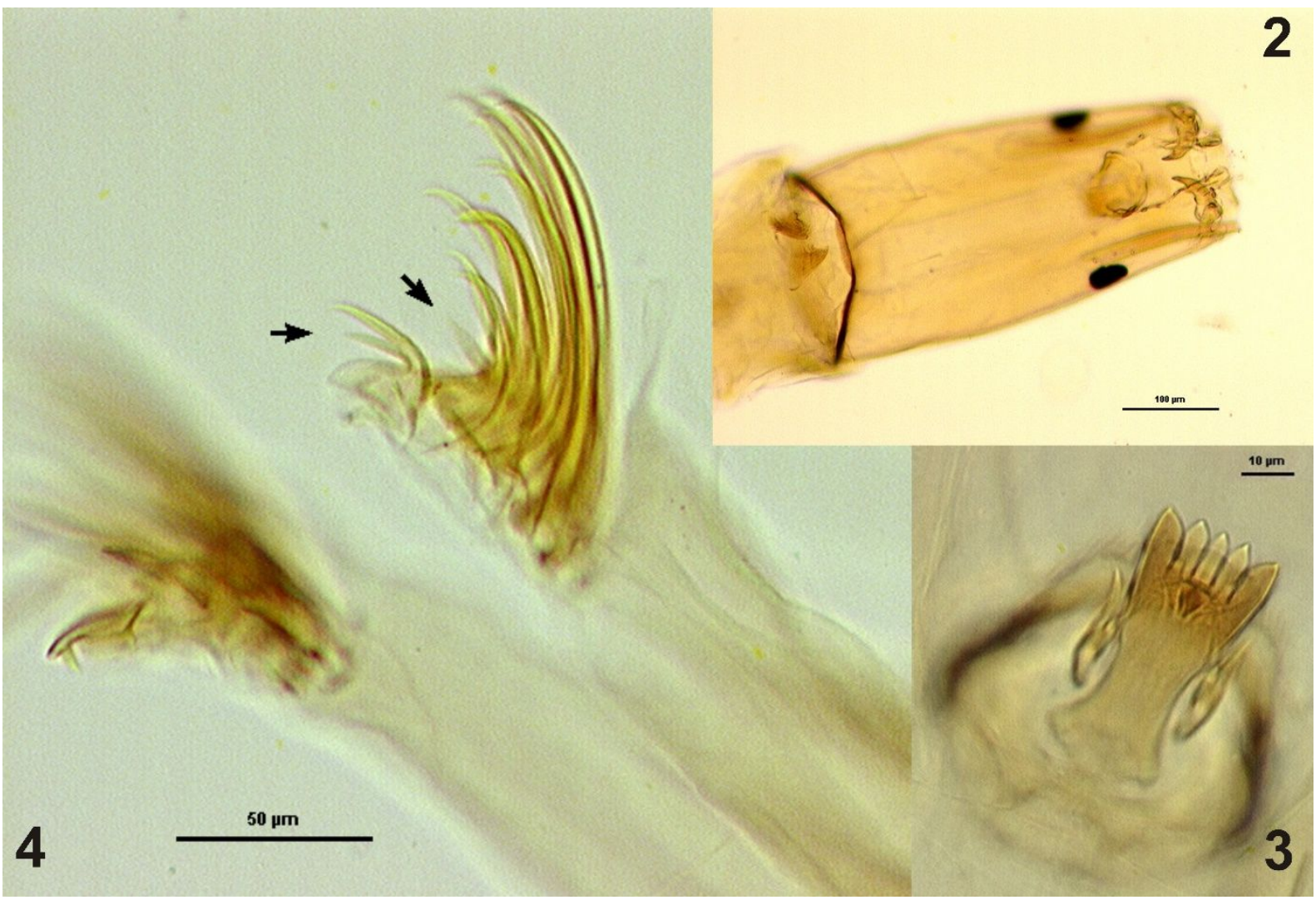

Figs 2-4: Schineriella schineri (Strobl, 1880), 2 - head, 3 - ligula, 4 - claws of posterior parapod (two double claws marked with arrows). Photos by S. Ščerbáková.

Acknowledgements: I am grateful to Dr. Miroslav Očadlík for collection of the identificated material and taking photograph of the locality used in the paper. The study was financially supported from the EU Cohesion Funds within the project Monitoring and assessment of water body status (No. 24110110158, 2012-2015 Phase II). 


\section{References}

Bitušík P. \& Brabec K. (2009): Chironomidae Newman, 1834.- In: Jedlička L., Kudela M. \& Stloukalova V. (2009): Checklist of Diptera of the Czech Republic and Slovakia.- Electronic version 2. http://zoology.fns.uniba.sk/diptera2009 + CD-ROM. ISBN 978-80-969629-4-5

Bitušík P. \& Hamerlík L. (2014): Príručka na určovanie lariev pakomárov (Diptera: Chironomidae) Slovenska, Čast' 2. Tanypodinae. Belianum, Vydavatel'stvo Univerzity Mateja Bela v Banskej Bystrici, 96 pp.

Vallenduuk H. J. \& Moller Pillot H.K.M. (2013): Chironomidae Larvae of the Netherlands and Adjacent Lowlands, General ecology and Tanypodinae. KNNV Publishing, Zeist, 144 pp.

Sæther O.A. \& Spies M. (2013): Fauna Europaea: Chironomidae. In Beuk P. \& Pape T. (eds): Fauna Europaea: Diptera, Nematocera. Fauna Europaea version 2.6, http://www.faunaeur.org

Wils on R.S. \& Ruse L.P. (2005): A guide to the identification of genera of chironomid pupal exuviae and their use in monitoring lotic and lentic fresh waters. - Freshwat. Biol. Assoc., 176 pp.

\section{Nový faunistický záznam druhu Schineriella schineri (Chironomidae: Diptera) zo Slovenska}

V rámci národného monitorovacieho programu sledovania stavu povrchových vôd Slovenska bola v roku 2015 študovaná fauna bentických bezstavovcov Číčovského ramena. Výskum sa uskutočnil v blízkosti vyhláseného chráneného územia NPR „Č́́čovské mótve rameno“, ktoré je zároveň zaradené do zoznamu Ramsárskych lokalít na Slovensku. Druh Schineriella schineri (Strobl, 1880) tu bol zaznamenaný na území Slovenska po prvýkrát.

Author's address: Soňa Ščerbák ová, Department of Hydrobiology, Microbiology and Ecotoxicology, Water Research Institute in Bratislava, Arm. Gen. L. Svobodu 5, SK-812 49, Bratislava, Slovakia. Email: scerbakova@vuvh.sk 